\title{
Breton Language
}

National Cancer Institute

\section{Source}

National Cancer Institute. Breton Language. NCI Thesaurus. Code C153866.

A Southwestern Brittonic Celtic language spoken in the Brittany area of France. 